\title{
'Garden White' Caladium - a University of Florida Cultivar for Sunny Landscapes and Large Containers ${ }^{1}$
}

\section{Zhanao Deng and Brent K. Harbaugh ${ }^{2}$}

Caladiums (Caladium xhortulanum) are tropical plants often used to provide color in shady locations in the landscape. White fancy-leaved cultivars are particularly popular for this use because they can create a striking contrast with surrounding grasses, flowers, shrubs, or trees. Commercial caladium plants are propagated asexually from tubers. The world production of caladium tubers is concentrated in south-central Florida, which provides more than $95 \%$ of commercial tubers used worldwide. A survey conducted in 2003 (Deng et al., 2005) showed that white fancy-leaved cultivars represented $28 \%$ of tuber production industry, i.e. white is the most popular color in caladium. Four cultivars, 'Aaron', 'Candidum', 'Candidum Junior' and 'White Christmas', accounted for over $90 \%$ of all white cultivars grown. Two white fancy-leaved caladium cultivars recently have been released from the University of Florida/IFAS caladium breeding program. 'Florida Blizzard' (Harbaugh et al., 2002) was released in 2002 because of its unique white color pattern and demonstrated potential to produce more leaves than major white fancy-leaved cultivars. It performs best in large containers or shady landscapes. 'Florida Moonlight' (Miranda and Harbaugh, 2003), released from our program in 2003, has superior vigor compared to 'June Bride' when grown in shady locations in outdoor landscapes. When buds are excised, it also makes an attractive potted plant because it produces many leaves.

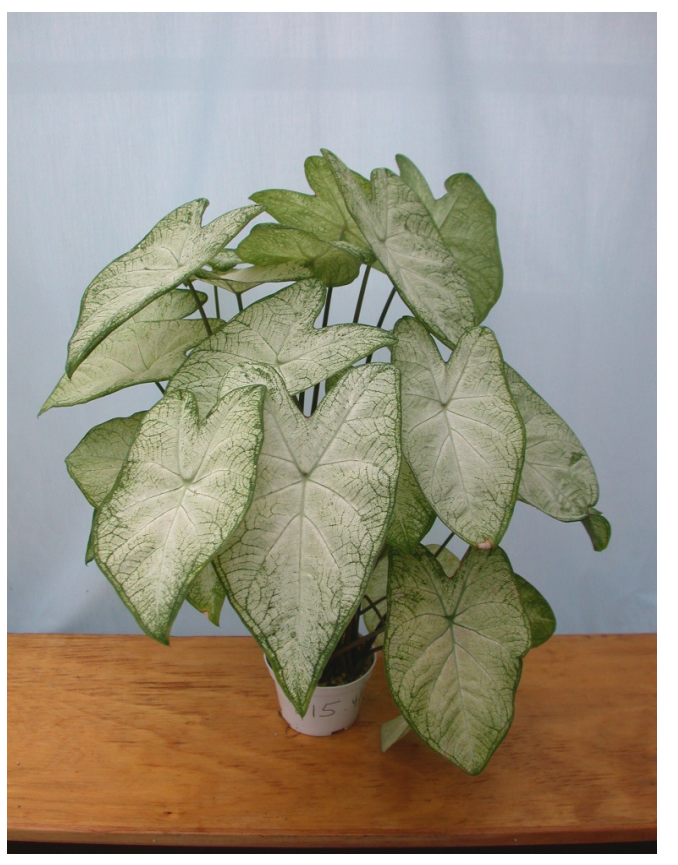

Figure 1. 'Garden White' forced in a 4.5-inch-container using one No. 1 tuber. Credits: University of Florida/IFAS GCREC

1. This document is EHN1041, one of a series of the Environmental Horticulture Department, Florida Cooperative Extension Service, Institute of Food and Agricultural Sciences, University of Florida. Original publication date June 1, 2006. Visit the EDIS Web Site at http://edis.ifas.ufl.edu.

2. Zhanao Deng, assistant professor, and Brent K. Harbaugh, professor, Gulf Coast Research and Education Center, Cooperative Extension Service, IFAS, University of Florida, Gainesville, 32611. 
'Garden White' is an extremely vigorous, large leaved, tall white fancy-leaved cultivar that is ideal for sunny landscapes and large containers. Its also has improved tuber production over the commonly grown white cultivars 'Aaron', 'Candidum', 'Candidum Junior', and 'White Christmas'.

\section{Origin}

'Garden White' was derived from a cross between 'Aaron' and 'Candidum Junior'. 'Aaron' was selected as the female parent because of its vigor, tuber yield, white-veined character, and excellent sun tolerance. 'Candidum Junior' was selected because of its leaf production and bright white color. Ancestry of 'Aaron' is unknown, while 'Candidum Junior' is believed to be a field mutation of 'Candidum' (Wilfret, 1991).

\section{Description}

Jumbo tubers are multi-segmented, bearing three to four dominant buds. Tuber surfaces are brown with the cortical area yellow-orange.

Leaves are peltate, sagittate-cordate, with white palmate-pinnate venation. The upper surface has a green margin, bordering the entire leaf, except for the basal leaf sinus where it is gray-purple. Interveinal areas are white. Leaves have a small red-purple blotch at the petiole attachment. Netted green venation occurs on $75 \%$ to $100 \%$ of the leaf surface. Primary veins are green-white, and netted venation is green and occurs over the entire leaf surface.

Interveinal areas are quite variable with a green-white color near the center to a gray-green near the margin. Petioles are light green at the apex, but the color diffuse into a dark brown at the base.

Leaves of 'Garden White' are relatively large compared to many other cultivars. The largest leaves on plants grown in a $25 \%$ shaded greenhouse produced from an intact, number-one tuber in a 5-inch pot averaged 13 inches long and 6-7 inches wide 7 weeks after planting. When grown from 1-inch tuber propagules in ground beds under full sun, leaves measured approximately 4 months after planting averaged 13 inches long and 7 inches wide. 'Garden White' plants grown for about 4 months in full sun in ground beds had an average height of 26 inches.

\section{Tuber Production}

'Garden White' was evaluated for tuber production and plant performance at the GCREC at Bradenton, Fla., in 2003 and the GCREC at Dover, Fla., in 2004. The soil in Bradenton was an EauGallie fine sand with about $1 \%$ organic matter and a $\mathrm{pH}$ of 6.2, and the soil in Dover was a Seffner fine sand with about $1 \%$ organic matter and a $\mathrm{pH}$ of 6.5 . Plants were grown in a plastic-mulched raised-bed system.

Osmocote 18N-2.6P-10K 8-to-9 month controlled-release fertilizer was applied to the bed surface when shoot tips were emerging from the soil with $\mathrm{N}$ at 300 pounds per acre.

Harvested tubers were graded by their maximum diameter: No. 2 (1 to 1.5 inches), No. 1 (1.5 to 2.5 inches), Jumbo (2.5 to 3.5 inches), Mammoth (3.5 to 4.5 inches), and Super Mammoth (> 4.5 inches). A production index was calculated as $\mathrm{N}(\mathrm{No} .2 \mathrm{~s})+2 \mathrm{~N}$ (No. 1s) + 4N (Jumbos) + 6N (Mammoth) $+8 \mathrm{~N}$ (Super Mammoth), where $\mathrm{N}=$ number of tubers in each grade, and used as an indicator of economic value of the crop harvested.

The weight of 'Garden White' tubers from each planting plot exceeded that of all other cultivars except 'June Bride' in 2003. In 2004, tuber weight of 'Garden White' was similar to that of 'Florida Moonlight' and 'White Christmas', but exceeded that of other cultivars except 'June Bride'. The production index was highest for 'Garden White' and 'June Bride' compared to all other cultivars in 2003. In 2004, the production index for 'Garden White' exceeded other cultivars except 'Florida Moonlight' and 'June Bride', which had similarly high values. 'Garden White' had more marketable tubers per plot (59) than all other cultivars in 2003, and a similar number of tubers (45) to 'Florida Moonlight' and 'White Christmas' in 2004. 'Garden White' had about $86 \%$ of tubers in the No. 1, Jumbo, and Mammoth categories. These sizes are ideal for tubers marketed for landscape use. 


\section{Container Forcing}

'Garden White' tubers were forced in 4 1/2-inch containers and its growth parameters were compared to that of four white fancy-leaved commercial cultivars. No. 1 tubers were planted in a peat-vermiculite mix (Vergro Container Mix A) on April 22, 2005. The study was conducted in a glasshouse with $25 \%$ light exclusion during the summer in Bradenton, Fla. Average daily temperatures ranged from a low of $70^{\circ} \mathrm{F}$ night to $85^{\circ} \mathrm{F}$ in the day during the experiment. Plant height, number of leaves, and foliar characteristics were recorded 7 weeks after planting.

'Garden White' tubers sprouted 25 days (intact) or 27 days (de-eyed) after planting and were earlier than all cultivars except 'Candidum', which had similar sprouting dates of 27 and 30 days after planting. Plants from intact tubers of 'Garden White' were 15 inches tall, similar in height to 'Aaron' and 'White Christmas', while plant height was 11 inches from de-eyed tubers. All cultivars had similar plant heights when tubers were de-eyed. 'Garden White' and 'Aaron' had only 4 leaves on plants grown from intact tubers, but 11 on plants grown from de-eyed tubers. 'Garden White' had the largest leaves of all cultivars tested. The performance of 'Garden White' from intact tubers suggested that it is best suited to landscape use. If used in small pots, 'Garden White' may perform better if tubers are de-eyed and treated with a growth retardant.

\section{Landscape Performance}

'Garden White' was grown under full-sun conditions in 2003 and 2004. Plant height, leaf number, and leaf size were measured approximately 4 months after planting. Overall landscape plant performance ratings of 'Garden White' were excellent for all rating periods (July 22, August 31, and November 16). 'Garden White' was the tallest cultivar evaluated in this test, outgrowing both parents.

\section{Summary}

In summary, 'Garden White' is intended for use in full sun or part shade landscapes or large containers. Its performance was outstanding for a white cultivar since, unlike most white cultivars, its leaves did not deteriorate under full sun conditions. Due to its vigor, height, and huge leaves, it is well suited as a garden or landscape plant.

Although extensive research and evaluations of this cultivar have been performed on small acreages, tuber producers are encouraged to plant only limited quantities of 'Garden White' until they have gained experience in producing this cultivar. Standard postharvest treatment of tubers is recommended (Harbaugh and Tjia, 1985) and preplant hot-water treatment of tubers is encouraged to prolong their life.

\section{Availability}

A patent is applied for for 'Garden White' by the Florida Agricultural Experiment Station, and production of this cultivar will be with a licensing agreement with the Florida Foundation Seed Producers, Inc., P.O. Box 309, Greenwood, FL 32443. Information on tuber availability and propagation agreements can be obtained from the Florida Foundation Seed Producers, Inc.

\section{Literature Cited}

Deng, Z., B.K. Harbaugh, R.K. Schoellhorn, and R.C. Andrew. 2005. 2003 Survey of the Florida caladium tuber production industry. UF/IFAS Extension Fact Sheet ENH 1007, 6 p. $<$ http://edis.ifas.ufl.edu/EP258>.

Harbaugh, B.K. and B.O. Tjia. 1985. Commercial forcing of caladiums. IFAS Univ. Fla. Agr. Ext. Serv. Circ. 621.

Harbaugh, B.K., B.D. Miranda, and G.J. Wilfret. 2002. 'Florida Blizzard'-A white fancy-leaved caladium for large pots or shady landscapes. HortScience 37:844-866.

Miranda, B.D. and B.K. Harbaugh. 2003. 'Florida Moonlight'—A white fancy-leaved caladium for pots and shady landscapes. HortScience 38:635-637.

Wilfret, G.J. 1991. Florida Sweetheart, a rose lance caladium for landscape and containers. IFAS Univ. Fla. Agr. Ext. Serv. Circ. S-380. 
Table 1. Plant performance approximately 4 months after planting 1 -inch tuber propagules in ground beds in full sun in 2003 and 2004. Values presented are means of three replications with three plants measured per plot per year, averaged over 2 years.

\begin{tabular}{|c|c|c|c|c|c|c|c|}
\hline \multirow[b]{2}{*}{ Cultivar } & \multirow[b]{2}{*}{$\begin{array}{c}\text { Plant height } \\
\text { (inch) }\end{array}$} & \multirow[b]{2}{*}{$\begin{array}{l}\text { Leaves } \\
\text { number }\end{array}$} & \multicolumn{2}{|c|}{ Leaf } & \multicolumn{3}{|c|}{ Overall plant performance rating ${ }^{z}$} \\
\hline & & & $\begin{array}{l}\text { Length } \\
\text { (inch) }\end{array}$ & $\begin{array}{l}\text { Width } \\
\text { (inch) }\end{array}$ & Early & Middle & Late \\
\hline Aaron & 21.2 & 16.3 & 11.4 & 6.9 & 3.8 & 4.0 & 3.2 \\
\hline Candidum & 18.1 & 13.3 & 11.1 & 7.1 & 3.3 & 3.7 & 3.5 \\
\hline Candidum Jr. & 10.3 & 15.9 & 8.7 & 5.7 & 2.8 & 2.5 & 2.7 \\
\hline $\begin{array}{l}\text { Florida } \\
\text { Moonlight }\end{array}$ & 20.9 & 18.4 & 10.9 & 7.9 & 5.0 & 4.5 & 4.3 \\
\hline Garden White & 26.1 & 17.0 & 12.8 & 7.1 & 4.7 & 4.5 & 4.2 \\
\hline June Bride & 20.0 & 13.0 & 12.2 & 7.6 & 3.7 & 4.3 & 3.2 \\
\hline White Christmas & 20.1 & 14.6 & 12.4 & 7.8 & 5.0 & 4.3 & 3.3 \\
\hline $\operatorname{LSD}(a=0.05)$ & 3.1 & 3.8 & 1.4 & 0.7 & 0.9 & 0.5 & 1.0 \\
\hline
\end{tabular}




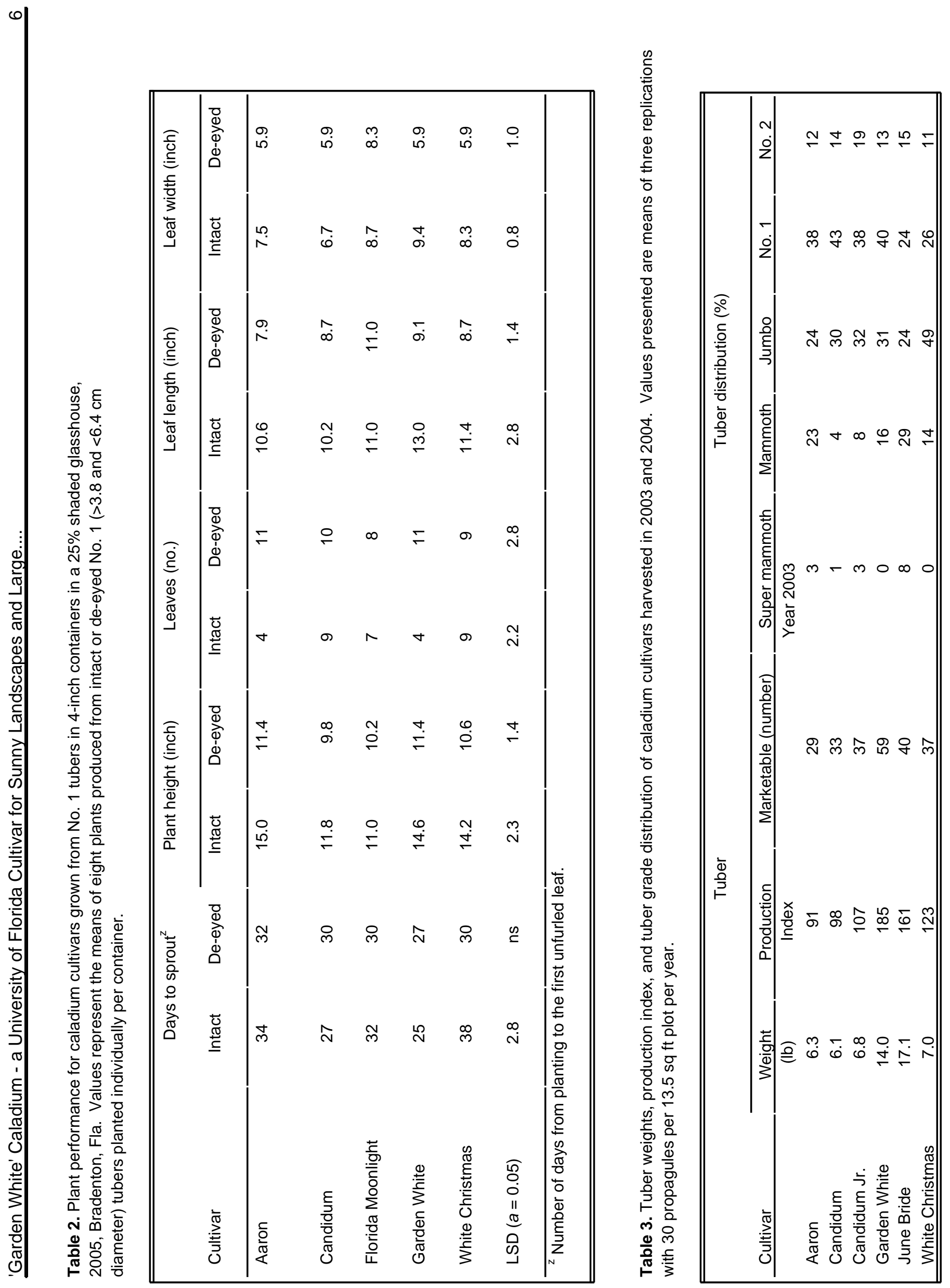




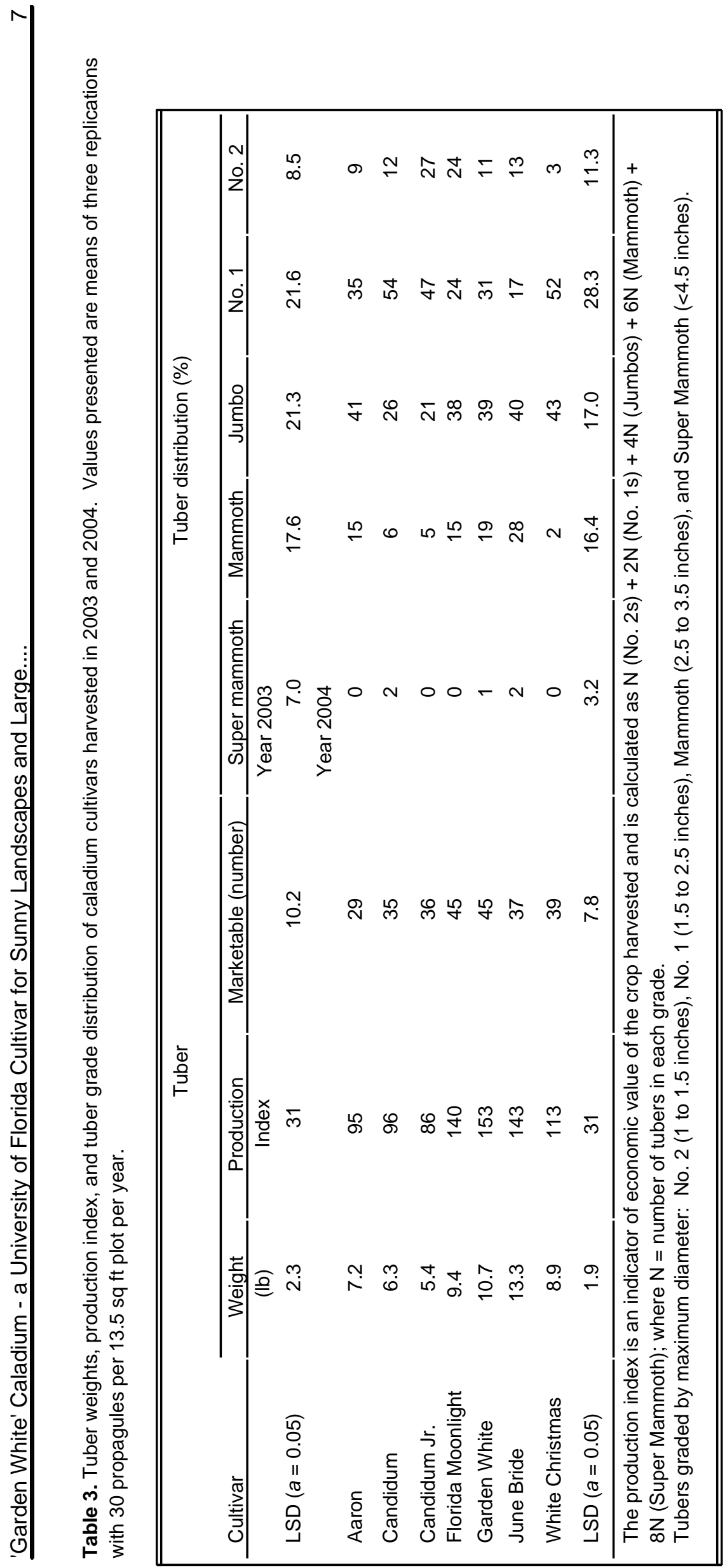

